\title{
AÇÃO, TIPICIDADE E CULPABILIDADE PENAL DA PESSOA JURÍDICA EM TEMPOS DE COMPLIANCE: UMA PROPOSTA INTERPRETATIVA
}

\author{
ACCIÓN, TIPICIDAD Y CULPABILIDAD PENAL DE LA PERSONA JURÍDICA EN \\ TIEMPOS DEL COMPLIANCE: UNA PROPUESTA INTERPRETATIVA
}

ACTUS REUS, MENS REA AND CRIMINAL CULPABILITY OF

CORPORATIONS IN TIMES OF COMPLIANCE: AN INTERPRETATIVE PROPOSAL

\begin{abstract}
Alfonso Galán Muñoz ${ }^{1}$
Professor Titular de Direito Penal, Universidad Pablo de Olavide.
\end{abstract}

\section{Resumo}

1. A incapacidade de ação e de culpabilidade da pessoa jurídica como pretenso obstáculo à possível existência da sua verdadeira responsabilidade penal. 2. A irrupção do Compliance no regime de responsabilidade penal das pessoas jurídicas. Identificação do seu específico papel normativo. 3. Violação de deveres preventivos e crimes alheios: Os dois referentes básicos do tipo objetivo do injusto pelo qual a pessoa jurídica é responsabilizada. 4. A existência de infração preventiva coletiva (não individual) como fundamento da responsabilidade da pessoa jurídica. 5. Princípio da culpabilidade e responsabilidade penal da pessoa jurídica: dolo ou culpa da pessoa jurídica?

Palavras-chave: Responsabilidade penal; Pessoa Jurídica; Tipicidade; Culpabilidade; Compliance.

\begin{abstract}
1. The incapacity of actus reus, mens rea and culpability of the corporations as an alleged obstacle to the possible existence of their true criminal liability. 2. The irruption of Compliance in the criminal
\end{abstract}

\footnotetext{
${ }^{1}$ Professor Titular de Direito Penal, Universidad Pablo de Olavide. Tradução do espanhol: Rodrigo Leite Ferreira Cabral, Doutor pela Universidade Pablo de Olavide e Professor do PPGD da Unibrasil.
} 
liability system of legal entities. Identification of its specific normative role. 3. Violation of preventive duties and crimes of others: The two basic referents of the actus reus for which the corporations are held responsibles. 4. The existence of a collective preventive offense (not individual) as a basis for the liability of corporations. 5. Principle of culpability and criminal liability of the corporations: Intention and negligence of legal entities?

Key-words: Criminal liability; Corporations; Actus Reus; Mens Rea; Culpability; Compliance.

\section{A INCAPACIDADE DE AÇÃO E DE CULPABILIDADE DA PESSOA JURÍDICA COMO PRETENSO ÓBICE À POSSÍVEL EXISTÊNCIA DE SUA VERDADEIRA RESPONSABILIDADE PENAL}

A entrada em vigor da Lei Orgânica espanhola n. 5/2010 parecia destinada a encerrar o tradicional debate doutrinário sobre a viabilidade da existência de uma verdadeira responsabilidade penal para as pessoas jurídicas. Concretamente, parecia que vinha a dar por superada a etapa da discussão sobre se era possível verificar tal responsabilidade e começava adentrar à questão de como deveria ser feita essa responsabilização².

No entanto, segue existindo na nossa doutrina um importante movimento de resistência à superação da primeira das referidas etapas. Isto é, ainda existe um importante setor doutrinário que, apesar do inquestionável teor literal do nosso Código desde 2010, continua a negar que ele permite imputar uma verdadeira responsabilidade criminal e serve para aplicar autênticas penas às pessoas jurídicas.

Não é, de modo algum, um dado desprezível, nesse sentido, que a Alemanha, referente fundamental de toda a elaboração da tradicional teoria geral do delito utilizado em nosso pais, continue sendo um dos poucos países europeus que continuam mantendo, ainda hoje, a validade do antigo princípio de que as sociedades não podem cometer crimes ou ser punidas, fato que inclusive levou a algum autor do alemão a afirmar, com certa ironia, que a Alemanha se apresenta no contexto europeu como um caso inverso da irredutível aldeia gaulesa de Asterix e Obelix contra sua possível absorção pelo Império Romano, visto que, enquanto esta permaneceu isolada para não se submeter à Roma, a Alemanha é aquela que agora aparece isolada do resto do

\footnotetext{
2 ZÚÑIGA RODRÍGUEZ, "Responsabilidad penal de las personas jurídicas y criminalidade organizada. Consideraciones de urgencia sobre la reforma penal de 2010", en Un Derecho penal comprometido. Libro homenaje al prof. Dr. Gerardo Landrove Díaz, Ed. Tirant lo Blanch, Valencia, 2011, pág. 1154.
} 
continente, justamente para manter a validade do antigo princípio romano de "Societas delinquere non potest" 3 .

O pensamento de resistência espanhol à aceitação do novo princípio de Societas delinquere potest encontra, sem surpresa, uma base sólida em alguns dos argumentos usados contra este princípio pela doutrina alemã para desprezá-lo e continuar no referido isolamento, mas também faz algumas críticas não tão pequenas sobre a própria configuração do sistema espanhol, bem como contra as propostas de interpretação que foram feitas em relação a ele para torná-lo viável e consistente com os princípios e garantias de um verdadeiro direito penal democrático; críticas que, de fato, levam esses autores a rejeitar de forma contundente a verdadeira natureza penal ou mesmo sancionatória do regime de responsabilidade já em vigor na Espanha.

Em relação ao primeiro, existe um certo consenso entre todos os que compartilham desse discurso de resistência na hora de entender que o fundamento último da responsabilidade penal das pessoas jurídicas nunca poderá ser uma conduta realizada pela própria entidade como tal, já que esta, por definição, carece de vontade própria e, por isso, sempre precisará atuar em nome de pessoas físicas.

Precisamente por este motivo e como consequência lógica do exposto, também se considera que é impossível entender que o Direito penal possa endereçar normas diretivas às pessoas jurídicas para que façam ou deixem de fazer alguma coisa, já que nunca poderiam cumprir, por si mesmas, o exigido, nem, consequentemente, será possível responsabilizá-las por não o ter feito.

Nesse sentido, Schünemann há muito já apontou que, mesmo quando se trate de fundamentar a infração normativa, que gera a pretensão de responsabilidade penal de ditas entidades, naquela produzida em relação a uma suposta norma de conduta dirigida a elas (por exemplo, uma que obrigue a implementação e execução de programas de compliance) e não aos indivíduos que materialmente cometeram os crimes em relação aos quais se busca responsabilizar, descobriríamos que esse mandato preventivo não se destinaria e seria, no caso, descumprido pela pessoa jurídica como tal, mas sim que teria como destinatário a uma ou várias pessoas físicas integradas à sua organização, que seriam as únicas que poderiam cumprir ou descumprir, o que geraria uma série de problemas.

O primeiro seria derivado do fato de que, tendo em vista que as normas que

\footnotetext{
${ }^{3}$ VOLK, K. "Sobre a responsabilidade penal das empresas", in Direito penal como crítica da pena. Estudos homenagem a Juares Tavares por seu $70^{\circ}$ Aniversario em 2 de setembro de 2012. Ed. Marcial Pons, Madrid, 2012, pág. 717.
} 
supostamente obrigariam a evitar o surgimento de um estado de incorreta organização preventiva só podem ser violadas por sujeitos individuais, se as pessoas jurídicas fossem punidas por sua infração, seriam punidas, na verdade, por fatos e infrações que teriam sido cometidos por terceiros que não eles (sujeitos individuais), caindo assim, aqueles que defendem que tal infração preventiva seja o fundamento último da responsabilidade penal das pessoas jurídicas, em uma fragrante contradição com o que é exigido pelo princípio da culpabilidade.

O segundo tem origem no fato de que, caso se fundamente a sanção ou penalidade da entidade, como alega a referida proposta, na violação de normas preventivas que supostamente obrigam as pessoas jurídicas a se organizarem preventivamente de determinada forma, isso implicaria que a punição da pessoa jurídica se fundaria na transgressão de uma norma (a preventiva) distinta daquela que delimita e define o injusto delitivo pelo qual ela seria responsabilizada e sancionada, algo que, evidentemente, vulneraria o princípio da legalidade, já que, ao fazê-lo, se estaria subsumindo "... na norma penal supostamente infringida, uma ação lesiva referida a outra norma, que é a norma de organização", punindo assim, conforme o delito em questão, uma conduta, como a organizativa, que não estará contemplada no seu tipo de injusto 4 .

Como era de se esperar, as comentadas e contundentes críticas à construção de um possível injusto organizativo próprio das pessoas jurídicas, realizada pelo referido autor, encontraram rápido eco na doutrina espanhola.

Assim ocorreu, por exemplo, com Robles Planas que, em clara sintonia com o comentado por Schünemann, afirmava que: "A pessoa jurídica não age independentemente das pessoas físicas. Nesse sentido, é um puro receptor de ações ou omissões. Consequentemente, é um estado de coisas objetivo, um mero contexto ou estrutura causal, que, certamente, pode ser apropriado para a prática de atos criminosos. Mas sobre a existência desse contexto só podem responder as pessoas físicas que 0 geraram por meio de suas ações ou que permitiram que ele fosse gerado por meio de suas omissões. A pessoa jurídica não pode impedir o que as pessoas físicas querem fazer, portanto, puni-las pressupõe torná-las responsáveis por fatos que jamais poderiam

\footnotetext{
${ }^{4}$ SCHÜNEMANN, B. "La responsabilidad penal de las empresas y sus órganos directivos en la Unión europea" en Constitución europea y Derecho penal económico. Mesas redondas Derecho y economía. Ed. Ramón Areces. Madrid, 2006, pág. 148 e ss. No mesmo sentido, já se manifestava o mesmo autor em "Responsabilidad penal en el marco de la empresa. Dificultades relativas a la individualización de la imputación" in ADPCP, Vol. LV, 2002, pág. 29.
} 
evitar." 5

Esse fato encontrou, na opinião do referido autor, um claro reflexo legislativo quando o art. 31 bis, CP espanhol, na sua versão anterior à reforma de 2015, excluía a possibilidade de atribuir à pessoa jurídica as circunstâncias relacionadas com a culpabilidade das pessoas físicas que materialmente praticaram os atos criminosos ou daqueles que "os tornaram possíveis por não terem exercido o devido controle" e também quando o art. 66 bis do referido texto normativo, ao estabelecer os critérios para a determinação das penalidades das pessoas jurídicas, afirmou que deveria levar em conta "o cargo ocupado na pessoa jurídica pela pessoa física ou jurídica que violasse o dever de controle"; ambas as expressões que, a seu ver, deixavam claro que quem pudesse violar e, se for caso disso, violar os referidos deveres de controle, pelos quais a entidade seria sempre e necessariamente responsabilizada, seria efetivamente uma pessoa física e não a própria pessoa jurídica ${ }^{6}$.

Considerar então que a responsabilidade penal da pessoa jurídica podia ser sustentada com base na existência de um ato próprio, decorrente de um defeito de organização ou de uma falta de controle exercido por ela, seria, portanto, simplesmente impossível.

Tal fato da entidade não existiria na realidade. Seria, nas palavras de Robles Planas, "uma ficção construída para ocultar a violação do princípio da culpabilidade", o que levou ao entendimento de que, na realidade, "por trás do falso véu da 'culpabilidade penal da pessoa jurídica' se oculta também a responsabilidade da pessoa física", sendo, portanto, "o denominado modelo de responsabilidade pelo próprio ato (...) uma versão refinada do modelo de responsabilidade por atribuição ou transferência (vicária)"7. Esse modelo, precisamente por esse motivo e como o vicário ou por transferência, renunciaria ao princípio da culpabilidade e suas exigências para poder estender as regras de imputação da responsabilidade penal a realidades alheias a ela (pessoas jurídicas), o que, na opinião do autor de que falamos, impediria que se pudesse conceder caráter realmente penal às suas regras e às supostas penas que seriam impostas ${ }^{8}$.

Por outro lado, e de forma totalmente consistente com o que Schünemann

\footnotetext{
${ }^{5}$ ROBLES PLANAS, R. "Pena y persona jurídica: Crítica del artículo 31 bis CP", Diario La Ley № 7705 , 2011, em http://diariolaley.laley.es (últ. vis. 1-9-2018).

${ }^{6}$ ROBLES PLANAS, R. "Pena y persona jurídica: Crítica del artículo 31 bis CP" cit. ant.

${ }^{7}$ ROBLES PLANAS, R. "El "hecho propio" de las personas jurídicas y el Informe del Consejo General del Poder Judicial al Anteproyecto de Reforma del Código Penal de 2008” Indret, №. 2, 2009, pág. 4 y 5, en http://www.indret.com/ (últ. vis. 9-4-2018).

8 Ibidem.
} 
defendia anteriormente, o referido autor continuou a apontar que os possíveis vícios de organização da pessoa jurídica não são, de forma alguma, suficientes para construir o injusto da pessoa jurídica em relação ao crime cometido pela pessoa física, porquanto não justificam sua participação no referido crime.

Assim, destacou Robles Planas, "é evidente que a pessoa jurídica não participa no crime que, no fim, é cometido pela pessoa física, pelo simples fato de ser 'desorganizada'. A presença de defeito organizativo-preventivo no seu interior permitiria fundamentar, no máximo e de forma questionável, a eventual responsabilidade da entidade pelo perigo abstrato de cometer o crime que esse defeito viesse a gerar. Um perigo, cuja criação - ademais de dificilmente poder fundamentar por si só um merecimento de pena a ser imposta à pessoa jurídica - , nunca e sob nenhum aspecto permitiria que se pudesse considerar culpável, a ela e seus titulares (verdadeiros destinatários últimos do novo dever organizativo), dos fatos delitivos concretos realizados por seus órgãos ou empregados, em relação aos quais o art. 31 bis do Código Penal espanhol, apesar de tudo, permitiria uma condenação ${ }^{9}$.

As semelhanças entre essa abordagem crítica sobre a possibilidade da existência de uma ação, de um injusto e de uma culpabilidade próprios das pessoas jurídicas e o defendido, recentemente e de forma bastante veemente, por Gracia Martíns são indubitáveis ${ }^{10}$.

O referido autor criticava duramente as opiniões daqueles que, já faz algum tempo, afirmaram que, apesar de ser evidente que a tradicional teoria do delito elaborada para regular ações realizadas por pessoas físicas, autoconscientes e dotadas de capacidade de formar uma verdadeira e autônoma vontade própria - não podia ser aplicada às pessoas jurídicas ${ }^{11}$,tal fato não impediria o desenvolvimento ou criação de

\footnotetext{
${ }^{9}$ ROBLES PLANAS, R. "Pena y persona jurídica: Crítica del artículo 31 bis CP" cit. ant.

${ }^{10}$ Também existem inegáveis similitudes entre essa fundamentação e o sustentado, há não muito tempo, por exemplo, por CIGÜELA SOLA, J. que o levavam a afirmar que a responsabilidade e as penas que se apliquem às pessoas jurídicas, de acordo com o que estabelece o art. 31 bis $\mathrm{CP}$, somente poderiam ser consideradas como penais em um sentido puramente formal: in La culpabilidad colectiva en el derecho penal. Critica y propuesta de una responsabilidad estructural de la empresa", Ed. Marcial Pons. Madrid, 2015, pág. 319 e ss. e in "El injusto estructural de la organización", in Indret, 1/2016, en http://www. indret.com/ (últ. vis. 9-8-2017), pág. 19.

${ }^{11}$ Nesse sentido, afirmava já há algum tempo GRACIA MARTíN, que as referidas incapacidades da pessoa jurídica levavam a que não fosse possível realizar condutas próprias, que pudessem dar lugar à apreciação das ações ou omissões que se requerem para iniciar o caminho que levaria à imputação de responsabilidade penal, conforme a citada teoria, diante do que sua carência de capacidade de ação impediria que se lhes pudessem atribuir os injustos típicos dos delitos, em relação aos quais se lhes pretendia responsabilizar: in "La cuestión de la responsabilidad penal de las propias personas jurídicas" in Dogmática penal, política criminal y criminología en evolución. Ed. Comares. Universidad de la Laguna, 1997, pág. 107 e ss. Em termos praticamente idênticos se manifesta de novo e mais recentemente o autor GRACIA MARTÍN, L. "Crítica a las modernas construcciones de una mal llamada responsabilidad penal de
} 
outro ou outros sistemas de imputação paralelos e diferentes do individual, que permitissem responsabilizar penalmente tais entidades, atendendo e tendo em conta suas especiais características e particularidades ${ }^{12}$.

Concretamente, Gracia Martín criticava todos aqueles que (como o que escreve estas linhas) entendiam e afirmavam, na época, que negar a possibilidade de imputar responsabilidade penal às pessoas jurídicas, observando os conceitos de capacidade de ação ou de culpabilidade elaborados e desenvolvidos para as pessoas físicas, era partir de "uma premissa equivocada" ao abordar dita questão ${ }^{13}$, já que considerávamos que caso se tentasse aplicar as definições de ditas categorias, criadas e delimitadas para determinados sujeitos (as pessoas naturais), a outros (pessoas jurídicas), que, por definição, não tinham as características dos primeiros, seria irremediavelmente necessário negar a sua aplicação a estes últimos sujeitos, entrando assim em um verdadeiro "círculo vicioso" sem solução"

Ele nos criticou por entender que aqueles que, assim como nos manifestamos, o havíamos feito sem refutar, na verdade, os argumentos dados por aqueles que recusavam tal responsabilidade, observando, precisamente, às referidas incapacidades das pessoas jurídicas ${ }^{15}$.

De fato, a seu modo de ver, aqueles que não compartilhavam dita recusa, partiam de um erro de base, já que o conteúdo das referidas categorias dogmáticas, que

la persona jurídica, En RECPC 18-05 (2016), pág. 8 e ss., criminet.ugr.es/recpc/ (últ. vis. 10-9-2018).

12 Assim, por exemplo, afirmava ZUGALDÍA ESPINAR, J. M.: “...las personas jurídicas son incapaces de acción (pero solo si a la acción se la define exclusivamente como comportamiento humano); las personas jurídicas son también incapaces de culpabilidad (pero solo si a la culpabilidad se le entiende exclusivamente en clave bío-psicológica) y las personas jurídicas son incapaces de pena (pero solo si a ésta se la concibe como castigo retributivo del mal uso de la libertad humana). Pero al margen de estos conceptos de acción y de culpabilidad exclusivos de la persona física, existen también unos conceptos de acción y de culpabilidad propios de la persona jurídica sobre los que es posible exigirle responsabilidad criminal sin violar ningún principio constitucional," La responsabilidad criminal de las personas jurídicas, de los entes sin personalidad y de sus directivos, Ed. Tirant lo Blanch, Valencia, 2013, pág. 61. De fato, já BRICOLA, F. afirmava que, na verdade, os problemas que supostamente apresentam ditas categorias do delito, com relação à pessoa jurídica, "não é um problema ontológico, mas um simples problema de definição", "Il costo del principio "societas delinquere non potest» nell'attuale dimensione del fenomeno societario", Riv. it. dir. e proc. pen., 1970, pág. 1030.

${ }^{13}$ GALÁN MUÑOZ, A. "La responsabilidad penal de la persona jurídica tras la reforma de la LO 5/2010: entre la hetero-y la autorresponsabilidad", en RGDP 16 (2011) http://www.iustel.com/ (últ. vis. 9-9-2018), pág. 31.

${ }_{14}^{14}$ AMPE, E. J. "Systemunrecht und Unrechtssysteme", ZstW, 106, 1994, pág. 315 e ss.

${ }^{15}$ GRACIA MARTÍN, L. "La serie «infracción-culpabilidad-sanción» desencadenada por individuos libres como síntesis jurídica indisoluble derivada de la idea y del concepto a priori del derecho". RECPC 18-18 (2016) en criminet.ugr.es/recpc/ (últ. vis. 10-9-2017), pág. 11. De fato, referido autor considera que dita tendência se inscreve no que denomina de "punitivista", que coloca em perigo a existência da Dogmática, mediante a construção arbitrária de outros conceitos de ação e culpabilidade, distintos aos da pessoa física, in: GRACIA MARTíN, L. "Crítica a las modernas construcciones de una mal llamada responsabilidad penal..." cit. ant., pág. 12. 
impediriam responsabilizar penalmente as pessoas jurídicas não constituiria, como defendíamos, um "ponto de partida" do pensamento que negava dita possibilidade, mas que, na verdade, era o "ponto de chegada" da fundamentação que obrigava a recusar$\mathrm{la}^{16}$.

Depois de realizar uma exposição das diferentes concepções que foram defendidas sobre o conceito de norma jurídica, afirmava Gracia Martín que, apesar de toda norma se originar em observância a juízos de valor, já que expressa algo que "deve ser" de um determinado modo, posteriormente, criará normas abstratas de valoração que se dirigem a todos e não a um determinado indivíduo.

Quando esses juízos se referente à ordenação da vida em comum, conforme a justiça distributiva, as normas de valoração resultantes se chamam normas de adjudicação ou de distribuição e determinam a adjudicação de bens e coisas valiosas e também de objetos e fatos valorados negativamente (danos, gastos e riscos). São juízos, de todo modo, impessoais referidos ao dever ser, que somente depois serão concretizados em um dever pessoal de um indivíduo determinado, para que possa ser realizado observando suas características subjetivas. Precisamente por isso, a violação de tais normas valorativas dará lugar a uma imputação de responsabilidade decorrente do estado objetivo de contrariedade do dever objetivo impessoal que não tem nada a ver com a responsabilidade pessoal do indivíduo, que devia ter cumprido o dever pessoal correspondente àqueles criados por tais normas ${ }^{17}$.

Nesse sentido, assinalava Gracia Martín que: "Os deveres impessoais de que se falou têm que ser realizados objetivamente em todos os casos. Sem embargo, as pessoas em relação a quem o Direito imputa como meros portadores deles, como não são outra coisa que uma forma pura de pensamento como unificação de todos os direitos e deveres de um determinado indivíduo, não têm a capacidade de ação necessária para realizá-los (...) somente o indivíduo é dotado de dita capacidade e, por isso, somente um determinado indivíduo poderá realizar o conteúdo do dever impessoal da norma de valoração". Assim, é necessário concretizar esse dever impessoal em um pessoa, em um indivíduo determinado, derivando esse dever pessoal "de um nível normativo sobreposto ao das normas de valoração e distribuição, constituído pelas normas de determinação da conduta dos indivíduos, diante do que somente indivíduos dotados de

\footnotetext{
${ }^{16}$ GRACIA MARTíN, L. "Crítica a las modernas construcciones de una mal llamada responsabilidad penal..." cit. ant., pág. 13.

${ }^{17}$ GRACIA MARTIIN, L. "La serie "infracción-culpabilidad-sanción..." cit. ant., pág. 32.
} 
capacidade de ação podem ser destinatários de normas de determinação"18.

Somente eles (os indivíduos) podem agir como causa livre (causa libera), capaz de ativar-se livremente e arbitrariamente, mais além das influências das causas necessárias, naturais ou cósmicas, diante do que, somente em relação a eles, têm sentido as normas de determinação. Essas normas, as de determinação, diferentemente das regras da natureza, não são necessárias, mas sim convencionais e, por isso, relativas e contingentes, e podem, portanto, ser infringidas. $O$ que obriga se ter que utilizar outro dispositivo de força, diferente da necessidade natural, para impor sua vigência; dispositivo que não pode ser outro que a cominação da imposição de um mal e, se for o caso, a aplicação e execução real de dito mal a quem as descumpra. É dizer, a ameaça e, se for o caso, a imposição de sanções em sentido estrito ${ }^{19}$.

Com isso, demonstra-se, na opinião do citado autor, que somente os indivíduos, ao serem causa libera, podem cometer infrações de normas de determinação e que somente ditas infrações são suscetíveis de serem reafirmadas mediante a ameaça e aplicação de verdadeiras sanções. Mas, além disso, ao ser a sanção uma forma de reafirmar a norma diretiva diante de sua infração e poder cometer-se essa apenas pelo indivíduo que a descumpriu, torna-se evidente que somente se poderá considerar e catalogar como verdadeira sanção aquela que é imposta à concreta pessoa física infratora e não a nenhuma outra, provocando-se assim que caso se atribua responsabilidade a um sujeito pelo estado de contrariedade à norma criado por outro, 0 que se the imputaria já não seria, na verdade, a infração realizada, mas sim o resultado contrário à norma de valoração causado por aquele sujeito que sim realizou a infração ${ }^{20}$, algo que não é suscetível de ser objeto em uma verdadeira sanção (pelo menos de uma pena).

Precisamente isso é o que, a seu modo de ver, acontecerá com a pessoa jurídica, já que se the atribui responsabilidade por condutas que, na verdade, sempre e necessariamente terão sido realizadas por algum ou alguns indivíduos concretos que a integram ${ }^{21}$.

Por outro lado, ainda estava pendente a questão da culpabilidade, que é a ponte necessária entre a infração e a sanção.

\footnotetext{
${ }^{18}$ GRACIA MARTÍN, L. "La serie "infracción-culpabilidad-sanción..." cit. ant., pág. 33.

${ }^{19}$ GRACIA MARTÍN, L. "La serie "infracción-culpabilidad-sanción..." cit. ant., pág. 46 e ss.

${ }^{20}$ GRACIA MARTÍN, L. "La serie "infracción-culpabilidad-sanción..." cit. ant., pág. 49 y 50 . En idénticos términos, el mismo autor en. "Crítica a las modernas construcciones de una mal llamada responsabilidad penal..." cit. ant., pág. 19.

${ }^{21}$ GRACIA MARTIIN, L. "La serie "infracción-culpabilidad-sanción..." cit. ant., pág. 59.
} 
O ponto de partida, de acordo com o comentado autor, é que a culpabilidade pressupõe um juízo de reprovação, que é realizado exclusivamente sobre a infração cometida pelo mesmo sujeito à quem se dirige dita reprovação (culpabilidade pelo fato), o que a diferencia da responsabilidade em geral que sim pode derivar de um fato alheio ${ }^{22}$. Por isso, uma vez que se afirmou que a infração normativa tão somente pode ser cometida por indivíduos, se deverá entender que o que se atribui ou se trate de imputar à pessoa jurídica, ao estar fundando nas infrações realizadas pelas pessoas físicas e não por ela mesma, será feito, no máximo, por considerá-la responsável que não é culpável por tal infração. Uma responsabilidade que não estará fundada, portanto, em qualquer infração ou descumprimento da pessoa jurídica, nem em sua culpabilidade em relação a eles, mas será sim uma responsabilidade puramente objetiva e decorrerá de uma norma de valoração fundamentada, precisamente, na "justa distribuição das cargas e custos sociais, e são a contrapartida dos bens e benefícios que decorrem do fato de se conviver, cada um com todos os demais, na sociedade" 23 .

Desse modo, de acordo com Gracia Martín, as pessoas jurídicas não podem infringir normas de determinação, nem podem ser consideradas como culpáveis por seu descumprimento. Por isso, não podem também ser destinatárias de sanções, nem mesmo de verdadeiras penas. Na verdade, a seu modo de ver, tudo isso leva a que a pessoa jurídica não possa ser sujeito do Direito penal ${ }^{24}$, já que, somente poderia ser considerada como responsável (não culpável) patrimonial (não pessoal) de uma infração alheia (a realizada por um ser humano) ${ }^{25}$, diante do que as medidas (que não são sanções) que lhe foram aplicadas nunca e em nenhuma hipótese poderiam ser consideradas como verdadeiras penas ${ }^{26}$.

Parece, portanto, e resumindo o até agora exposto, que aquele que considere que as pessoas jurídicas não podem ser destinatárias de normas de determinação preventivas, por entender que não poderiam cumpri-las diretamente, impediria que se Ihes pudesse chegar a atribuir verdadeira responsabilidade penal por delitos eventualmente cometidos em seu seio, já que, nem seria possível responsabilizá-las

\footnotetext{
${ }^{22}$ GRACIA MARTíN, L. "La serie "infracción-culpabilidad-sanción..." cit. ant., pág. 67 y 68.

${ }^{23}$ GRACIA MARTÍN, L. "La serie "infracción-culpabilidad-sanción..." cit. ant., pág. 77.

${ }^{24} \mathrm{De}$ fato, chega a firmar que tentar atribuir responsabilidade penal e aplicar verdadeiras penas às pessoas jurídicas acaba sendo tão absurdo como querer fazê-lo com relação aos animais, in: GRACIA MARTíN, L. "Crítica a las modernas construcciones de una mal llamada responsabilidad penal..." cit. ant., pág. 74 e ss.

${ }^{25}$ GRACIA MARTÍN, L. "La serie "infracción-culpabilidad-sanción..." cit. ant., pág. 99. Em termos similares: GRACIA MARTÍN, L. "Crítica a las modernas construcciones de una mal llamada responsabilidad penal..." cit. ant., pág. 81.

${ }^{26}$ GRACIA MARTÍN, L. "La serie "infracción-culpabilidad-sanción..." cit. ant., pág. 115.
} 
pela suposta infração preventiva referida sem infringir flagrantemente o princípio da culpabilidade, nem parece que tal infração preventiva, caso ocorresse, seria suficiente para que fosse possível considerá-la responsável pelo injusto concreto do delito cometido $^{27}$.

\section{A IRRUPÇÃO DO COMPLIANCE NO SISTEMA DE RESPONSABILIDADE PENAL DAS PESSOAS JURÍDICAS. ESPECIFICAÇÃO DO SEU CONCRETO PAPEL NORMATIVO.}

A aprovação e entrada em vigor da reforma realizada pela LO 1/2015 teve um efeito notável sobre o sistema de responsabilidade penal previsto em relação à pessoa, chegando inclusive algum autor a afirmar que sua aprovação pressupôs, apesar do que dizia o preâmbulo da referida Lei Orgânica, muito mais do que um simples melhoramento da técnica do sistema previamente existente ${ }^{28}$.

De fato, a reforma incidiu de forma evidente em praticamente todos os pilares do sistema. O fez tanto na delimitação das regras de imputação de responsabilidade de ditas entidades (contido agora em todo um grupo de preceitos, que vão deste o art. 31 bis até 0 art. 31 quinquies do $\mathrm{CP}^{29}$ ), como sobre aqueles outros que estabelecem as regras de fixação das penas que podem lhes ser impostas (art. 66 bis CP) ou nos que fixam como agir diante do não pagamento de multas impostas às pessoas jurídicas (art. $53 \mathrm{CP}$ ).

Sem embargo, e apesar das numerosas e profundas modificações realizadas, existe uma que conseguiu, sem sombra de dúvidas, eclipsar todas as demais. Trata-se

\footnotetext{
${ }^{27}$ Também contra a possível atribuição de responsabilidade penal às pessoas jurídicas, em virtude das suas já clássicas incapacidades de ação, de culpabilidade e de punibilidade, mas também abordando a necessidade e conveniência político-criminal do reconhecimento da responsabilidade de tais entidades, manifestou-se, recentemente, por exemplo, DÍAZ Y GARCÍA CONLLEDO, M. in "¿Responsabilidad penal de las personas jurídicas? Algunas tesis", in Revista Justiça e Sistema Criminal, v. 10, n. 18, 2018, pág. 22 e ss.

${ }^{28}$ FEIJOO SÁNCHEZ, B. El delito corporativo en el Código penal español; Ed. Thomson Reuters. Cizur Menor, 2015, pág. 11.

${ }^{29}$ Nesse sentido e, ainda que não sem razão, QUINTERO OLIVARES, G. quando assinala que as principais modificações se centram no extenso novo art. 31 bis $\mathrm{CP}$, não cremos que se possa afirmar assim simplesmente, como faz o autor, que o resto dos preceitos referidos à fundamentação do sistema de imputação de responsabilidade de ditos sujeitos venham apenas a re-situar o anteriormente estabelecido, os artigos que, até a sua aprovação, regulavam o art. 31 bis, 2, 3 e $4 \mathrm{CP}$, in "La reforma del régimen de responsabilidad penal de las personas jurídicas", en Comentarios a la reforma del Código penal de 2015. Ed. Aranzadi. Cizur Menor, 2015, pág. 78, já que com isso se esqueceria também que o art. 31 quinquies $\mathrm{CP}$ voltou a reduzir o número das pessoas jurídicas que permanecerão à margem do dito sistema de responsabilidade, ao incluir, entre as que estariam subjetivas a eles, as "sociedades mercantis públicas que executem políticas públicas ou que prestem serviços de interesse econômico". Veja-se, em tal sentido, por exemplo, o comentado por DOPICO GOMEZ-ALLER, J., que expressamente assinala que a LO 1/2015 como a que introduziu a possibilidade de atribuir responsabilidade penal às sociedades mercantis públicas, in Memento penal Francis Lefebvre penal, Ed. Lefebvre-El Derecho, Madrid, $2016 \S 3119$.
} 
da derivada da expressa inclusão normativa dos denominados programas de Compliance ou de cumprimento normativo. Programas esses que, caso cumpram os requisitos contemplados no art. 31 bis $5 \mathrm{CP}$ e se implantem e executem de forma correta, podem levar inclusive à isenção de qualquer responsabilidade das pessoas jurídicas pelos delitos ou, para ser mais exatos, pelos fatos típicos e antijurídicos, que eventualmente tenham cometidos os sujeitos individuais a que aludem as alíneas "a" e "b" da nova redação do art. 31 bis 1 do Código Penal.

O poder atrativo que teve a expressa alusão normativa aos Compliance Programs como requisito da possível isenção completa de responsabilidade penal das pessoas jurídicas por tais delitos, levou a que o debate doutrinário tenha se centrado primordialmente no estudo dos requisitos e efeitos de ditos programas, deixando o resto das questões referidas à sua possível responsabilidade, assim com o resto das reformas realizadas em relação a específica regulação da mesma completamente eclipsadas e um segundo plano absoluto ${ }^{30}$.

Sem embargo, dito poder atrativo não pode nos levar a esquecer do fato de que o sistema de responsabilidade penal das pessoas jurídicas, vigente na Espanha, não Ihes faz responder tão somente por não implantar algum dos ditos programas (de fato, nem sequer impõe a obrigação de estabelecê-los), mas sim responsabiliza pela realização ou causação de fatos delitivos. Concretamente, e para ser preciso, a responsabilidade pelos fatos típicos e antijurídicos que constituem qualquer dos crimes que preveem a possível responsabilidade de tais entidades e que tenham, ademais, sido praticados por seus dirigentes ou por seus subordinados, ou por aqueles que estejam sujeitos ao controle dessas pessoas, em benefício direto ou indireto da pessoa jurídica e, em seu nome e por sua conta ou no exercício de suas atividades próprias ${ }^{31}$.

Essa observação nos leva a considerar que, para delimitar o sistema, deve-se partir de uma pergunta fundamental: Por que se responsabiliza ditas entidades por um delito que teria sido cometido por uma pessoa física diferente delas?

A nosso modo de ver, a resposta a essa pergunta somente pode ser uma. As pessoas jurídicas podem responder e responderão por fatos delitivos cometidos por determinados indivíduos que atuam em sua estrutura ou colaboram com ela, porque o Estado decidiu obrigá-las a envolver-se e colaborar na prevenção de tais fatos, em

\footnotetext{
${ }^{30}$ FEIJOO SÁNCHEZ, B. El delito corporativo en el Código penal español cit. ant., pág. 12.

${ }^{31}$ Sobre o que todos esses requisitos representam, veja-se o comentado por GALÁN MUÑOZ, A. Fundamentos y límites de la responsabilidad penal de las personas jurídicas tras la reforma de la lo 1/2015. Tirant lo Blanch, Valencia, 2017, pág. 119 e ss.
} 
relação aos quais estabeleceu o dever legal de preveni-los e previu a possibilidade de puni-las pela ocorrência de tais delitos, caso não cumpram com dito dever e, por isso, acabam facilitando que alguém possa cometer nas atividades da entidade e em seu benefício.

Com efeito, em primeiro lugar, existe um dever de impedir ou prevenir determinados delitos. Um dever preventivo que, a nosso juízo, aparece refletido ao largo de todo o complexo articulado que delimita os contornos da possível responsabilidade das pessoas jurídicas, mas que, ademais e de fato, está expressamente mencionado em alguns dos ditos preceitos.

Concretamente, esse dever aparece citado em várias ocasiões no parágrafo 5 do art. 31 bis CP; preceito que, por exemplo, ao estabelecer os requisitos que devem ser cumpridos por um programa preventivo de uma pessoa jurídica, para mantê-la isenta de responsabilidade pelos delitos de seus dirigentes e subordinados, afirma expressamente que $1^{\circ}$ deve criar um mapa de riscos da entidade referido aos "delitos que devem ser prevenidos"; enquanto que, por outro lado, obriga, em seu requisito $3^{\circ}$, que se estabeleça um sistema financeiro adequado, precisamente "para impedir o cometimento dos delitos que devem ser prevenidos".

Interpretar essas referências legislativas de outra forma que não seja a de considerá-las como expressamente referidas à existência de um dever de prevenir ou impedir os delitos delimitados no parágrafo 1 do art. 31 bis CP é, a nosso ver, praticamente impossível.

O problema, então, uma vez que se definiu o que se deve fazer (prevenir delitos), será determinar como se deve fazê-lo, para que se possa considerar cumprida dita obrigação ou dever e a pessoa jurídica ficaria, consequentemente, à margem de qualquer possível responsabilidade pela efetiva realização de algum dos injustos que deveria prevenir, ainda que esses ocorram; questão que o legislador de 2015 dizia expressa e especificamente que pretendeu responder com sua reforma.

Em concreto, o Preâmbulo da LO 1/2015, que efetuou dita reforma, afirmava que a modificação do sistema de responsabilidade penal da pessoa jurídica realizada pela lei tinha “... a finalidade de delimitar adequadamente o conteúdo do 'devido controle', cuja violação permite fundamentar a responsabilidade penal". Isto é, seu articulado havia buscado primordialmente delimitar o modo com que se deveria cumprir o dever de prevenir determinados delitos que nosso ordenamento assinala às pessoas jurídicas, para que pudessem ficar isentas de pena. E o havia feito, precisamente, delimitando nos 
parágrafos 2 a 5 do art. 31 bis CP as condições, - dentre as quais estaria a implantação de um adequado programa de Compliance -, que, no caso de ocorrer determinariam que se tivesse que considerar como cumprido de forma completamente adequada e irrepreensível o dever preventivo estabelecido, mantendo-se, portanto, a atividade da pessoa jurídica dentro do âmbito geralmente permitido, diante do que não poderia acarretar-Ihe nenhuma responsabilidade em relação a esses delitos.

Se concretizavam ou perfilhavam assim as condutas que deveriam ser realizadas e mantidas na pessoa jurídica para considerar que havia cumprido de forma plenamente diligente com a obrigação preventiva estabelecida, diante do que se compreende perfeitamente que o legislador fale sobre os preceitos nos quais define e delimita 0 modelo de cumprimento do estabelecimento de condições ou requisitos que "eximiriam" de responsabilidade penal as pessoas jurídicas, já que, na verdade, o que faz, ao estabelecê-los, não é descrever de forma positiva a conduta ou condutas que poderão fundamentar sua responsabilidade, mas sim, precisamente, as delimita negativamente, ao definir aquelas que deixariam a atividade realizada dentro do âmbito do geralmente permitido, mantendo a entidade em questão à margem de qualquer possível responsabilidade penal ${ }^{32}$.

Temos, portanto, uma norma de determinação que obriga a prevenir determinados delitos e temos uma série de requisitos que concretizam a forma e o modo com que se deve cumprir esse dever, para que se possa considerar como cumprido adequadamente o exigido por ele.

Sem embargo, a existência de todas essas prescrições não consegue responder a duas das principais críticas que, como vimos, têm sido feitas contra os intentos até agora realizados para atribuir responsabilidade às pessoas jurídicas pelos delitos que determinadas pessoas físicas cometem, com base na existência de determinadas infrações preventivas.

Nem determinam a razão pela qual a infração ou o incorreto cumprimento do referido dever preventivo poderão e, em determinados casos, farão com que as pessoas

\footnotetext{
${ }^{32}$ Não falta razão, portanto, a FEIJOO SÁNCHEZ, B., quando assinala, como vimos, que nesse caso o legislador, como frequentemente faz, delimitou um dos fundamentos sustentadores da responsabilidade penal das pessoas jurídicas de forma negativa. Isto é, descrevendo tão somente as circunstâncias que descartam dito fundamento, in "Réplica a Javier Cigüela. Ao mesmo tempo, algumas considerações sobre os últimos desenvolvimentos em responsabilidade criminal de pessoas jurídicas: Circular de la Fiscalía General del Estado 1/2016 y Sentencias del Tribunal Supremo 154/2016, de 29 de febrero y 221/2016, de 16 de marzo", in Indret, №. 2, 2016, in http://www. indret.com/ (últ. vis. 9-8-2017) pág. 30.
} 
jurídicas tenham que responder por determinados delitos, de que fala o parágrafo 1 do art. 31 bis, nem tampouco da adequada resposta àqueles que rechaçavam a possível atribuição de responsabilidade penal às pessoas jurídicas, por entender que, inclusive se dita responsabilidade se sustentasse sobre a base de uma infração de uma norma preventiva, se estaria responsabilizando por uma conduta que não havia efetivamente sido realizada pela entidade, mas sim por indivíduos concretos, diante do que ela teria que responder por um injusto alheio, infringindo, dentre outras coisas e de forma manifesta o princípio da culpabilidade.

\section{INFRAÇÃO DE DEVERES PREVENTIVOS E DELITOS ALHEIOS: OS DOIS REFERENTES BÁSICOS DO TIPO OBJETIVO DO INJUSTO DAQUELE QUE SE RESPONSABILIZA PELA PESSOA JURÍDICA.}

Como vimos, as pessoas jurídicas respondem por delitos, não simplesmente pela não realização de atuações que previnam sua realização ou pelos perigos delitivos que, diante da ausência de ditas medidas preventivas, podem ocorrer. Concretamente, respondem por delitos que cometam outros sujeitos (os indivíduos), o que obriga a buscar a razão que justifique a sua responsabilização por tais fatos, apesar de terem sido cometidos por terceiros.

O primeiro que se deve ressaltar em relação a essa questão é que o delito do indivíduo não é, nem pode ser, uma mera condição objetiva de punibilidade ou da responsabilidade da pessoa jurídica. De fato, o delito individual a prevenir constitui, desde o primeiro momento, o referente básico e fundamental em relação ao qual se deve verificar para definir as condutas preventivas que devem ser realizadas para que a pessoa jurídica fique isenta de qualquer responsabilidade penal pela sua execução e, consequentemente, também para determinar quais atuações violaram o dever preventivo anteriormente comentado e abriram, por isso, as portas para a sua possível responsabilização penal.

Somente assim se entende que o ponto de partida dos modelos preventivos ou programas de Compliance de que fala 0 art. 31 bis $5 \mathrm{CP}$ tenha que ser sempre e necessariamente a realização de um mapa de risco delitivo ajustado às concretas atividades que realize a entidade; mapa que, evidentemente, deverá realizar um prognóstico ou previsão ex ante da possível realização dos delitos que tenha que prevenir na entidade, observando sempre as suas concretas características (p. ex. atividades, 
organização, tamanho, etc...). Se não existe previsibilidade ex ante sobre a possível comissão de um delito de uma pessoa jurídica, nem surge o dever de fazer nada para preveni-lo, nem é possível haver infração alguma do dever preventivo que o ordenamento Ihe dirige, nem, consequentemente, é possível atribuir responsabilidade penal pelo mero fato de que o delito imprevisível em questão chegue, apesar de tudo, a ocorrer.

Partindo disso, não há mais remédio senão o de entender que o delito cometido, ou melhor dito neste momento, o que previsivelmente poderia ser cometido por algum dos indivíduos descritos no art. 31 bis $1 \mathrm{CP}$, não é algo alheio ao injusto derivado da quebra do dever preventivo predicado pelo nosso Código Penal em relação às pessoas jurídicas. Pelo contrário, constitui a referência principal e mais básica da referida infração e, portanto, também do risco não permitido que a dotará de conteúdo de material a antijuridicidade.

Por isso, se frequentemente se exige, como nosso Código faz, que dito delito chegue efetivamente a ser cometido para poder atribuir-se à pessoa jurídica em questão responsabilidade penal por sua realização, parece que o mais lógico é pensar que isso se deve a que o efetivo cometimento do referido delito individual delimita e determina o resultado do injusto do qual ela será responsabilizada, não sendo nem atuando, portanto, como uma mera condição objetiva de sua responsabilidade.

Desse modo, enquanto que o risco do cometimento do delito individual funciona como referente inicial para o desvalor de ação da conduta preventivamente infratora, necessária para que se possa responsabilizar uma entidade pela sua realização, sua efetiva comissão delimitará o concreto desvalor de necessário resultado do injusto que permitirá fazê-lo.

É por isso que, uma vez que se afirma que o art. 31 bis CP estabelece o dever de garantir que se controlem determinados riscos delitivos (não de todos) e se considera que ocorrência do delito não deixaria de ser nada mais que o resultado derivado do risco não permitido gerado como consequência da infração de dito dever, se abrem as portas para que se possa entender, como, por exemplo fez na época Gómez-Jara Díez, que o que realmente permitirá que se possa responsabilizar as pessoas jurídicas pelos delitos cometidos por seus indivíduos não será, como alguns entenderam, que tal delito seja uma materialização da "cultura criminógena" imperante na entidade ou da "ausência de uma cultura de cumprimento" em seu seio, mais, precisamente, o fato de que alguns dos riscos delitivos procedentes da infração preventiva realizada chegue a efetivamente 
materializar-se ou realizar-se no concreto delito realizado ${ }^{33}$.

Assim, portanto, para que se possa responsabilizar a pessoa jurídica por um delito, não bastará que exista ou que se crie indevidamente um risco delitivo não permitido, como consequência da defeituosa organização ou do incorreto funcionamento preventivo da empresa e, posteriormente, ocorra um delito na entidade completamente desconectado do risco em questão, mas sim que responda a parâmetros subjetivos e objetivos que definem os delitos em relação aos quais ela poderia responder, conforme o parágrafo 1 do art. 31 bis CP. É necessário que exista uma relação de causalidade entre a infração preventiva produzida e o delito realizado; relação que evidentemente deverá ser valorada e determinada de acordo com os critérios próprios da teoria da imputação objetiva.

Contudo, resta evidente que $\mathrm{o}$ delito em questão não decorre direta $\mathrm{e}$ exclusivamente da infração preventiva realizada na entidade. Decorre e, de fato, é dominado pelo sujeito individual que o localiza (por algum dos dirigentes ou subordinados delimitados no art. 31 bis $1 \mathrm{CP}$ ), o que, a nosso modo de ver, obriga a entender que, em que pese a entidade possa responder por tal delito, não será responsável, nem poderá sê-lo por ter dominado a sua ocorrência, mas sim somente por ter contribuído para que dito terceiro tivesse podido efetuar tal e como feito, sendo, portanto, a contribuição ao injusto delitivo ocorrido derivada do risco indevidamente não controlado a partir da entidade, e não no delito como tal, o resultado que determinará que se possa ter como corresponsável do concreto injusto cometido.

Desse modo, a pessoa jurídica será responsabilizada por não ter evitado que acontecesse, em seu seio, uma contribuição ao delito realizado por um sujeito individual que podia e deveria ter impedido, sendo dita contribuição ao resultado a que permitirá que a entidade possa responder pelo fato delitivo, que, na verdade, foi realizado e dominado por um terceiro.

O primeiro que deve ocorrer para tanto é que se crie ou aumente, de forma não permitida, o risco ex ante da ocorrência do delito em questão, ao não controlar um risco

\footnotetext{
${ }^{33}$ GÓMEZ-JARA, DíEZ, C. "El injusto típico de la persona jurídica (tipicidad)" in Tratado de Responsabilidad penal de las personas jurídicas. Ed. Thomson Reuters, Cizur Menor, 2016, pág. 126 e ss. Sobre a necessidade de exigir a ausência de uma cultura adequada de cumprimento normativo na entidade, como fundamento último de sua responsabilidade pelo delito cometido pelo indivíduo, veja-se o comentário, por exemplo, de NIETO MARTíN, A. in La responsabilidad penal de las personas jurídicas: Un modelo legislativo. Ed. Iustel. Madrid, 2008, págs. 145 e ss. ou, mais recentemente, in "Problemas fundamentales del cumplimiento normativo en el Derecho penal", in Compliance y teoría del Derecho penal, Ed. Marcial Pons, Madrid, 2013, pág. 30 e ss. ou, por FEIJOO SÁNCHEZ, B. in El delito corporativo... cit. ant., pág. 102 ou in "Réplica a Javier Cigüela..." cit. ant., pág. 6 e ss.
} 
previsível e existente tal e como deveria ter feito, o que ocorrerá, por exemplo, tanto se não previu em seu seio um programa de Compliance adequado, como se, existindo um perfeitamente válido, ele acaba não se executando de forma real e efetiva, no dia a dia da entidade. Sem embargo, isso não será suficiente para responsabilizar a entidade. Além disso, e por outro lado, será necessário que o risco não devidamente controlado pela inadequada execução da dita medida esteja referido, de forma específica, à possível ocorrência de delitos como o que efetivamente ocorreu e não a outro ou outros delitos de natureza diversa desse.

Não bastará, portanto, que exista qualquer defeito ou carência preventiva derivada da infração do dever preventivo predicável em relação à entidade.

A carência preventiva deve aumentar o risco de produção ex ante do delito em relação ao qual se pretende responsabilizar a entidade (p. ex. uma carência referida ao perigo do cometimento de lavagem de dinheiro não permitirá responsabilizar a pessoa jurídica pelo cometimento de um delito de tráfico de drogas, enquanto que a ausência de uma carência referida à prevenção de delitos de corrupção não poderá definir que se responsabilize por tráfico de órgãos). No entanto, além disso, uma vez que se constate que o incorreto controle preventivo realizado permitiu o aumento não permitido do risco da ocorrência de delitos, como o efetivamente realizado, isso somente possibilitará responsabilizar a pessoa jurídica pela sua ocorrência se restar comprovado, também, de uma forma ex post que foi, precisamente dito risco, e não outro, o que permitiu a realização em concreto do fato delitivo. Não será suficiente, portanto, a existência de defeitos ou vícios preventivos referidos ao mesmo tipo de delitos efetivamente cometidos. É necessário que a falha produzida e, em concreto, o risco não permitido que dito defeito gerou seja o que materialmente ocorra no concreto crime realizado, tendo, portanto, alguma incidência efetiva em sua comissão.

Será necessário, portanto, que a incorreta atuação preventiva ocorrida na entidade permita um aumento não permitido do risco da ocorrência de delitos como o cometido, que chegue a efetivamente se materializar na facilitação do concreto crime cometido. Somente assim será possível compreender que a pessoa jurídica pode responder por uma conduta delitiva que, na verdade, realizou e dominou um sujeito autônomo e distinto dela. Uma pessoa física. O que fará com que a incorreta previsão, gestão ou controle do risco, que o ordenamento jurídico impunha que se controlasse e prevenisse, deu lugar a que se gerasse ou aumentasse de forma indevida e não permitida o risco do cometimento de um delito que acabou ocorrendo, na sua efetiva realização 
por parte de um indivíduo que atuava dentro das atividades próprias da entidade e em seu benefício, favorecendo, de tal maneira, indevidamente seu cometimento.

Essa última exigência (a da realização do risco não permito no delito cometido) será determinante, por exemplo, para a impossibilidade de se atribuir responsabilidade àquela pessoa jurídica na qual não foram estabelecidas medidas preventivas da criação de "caixas 2", para evitar delitos de corrupção perfeitamente previsíveis e evitáveis em seu seio ou na que não foram aplicadas as medidas previstas em seu, em princípio, correto programa de Compliance, se o concreto delito de corrupção cometido por um de seus administradores houvesse sido cometido sem empregar ou aproveitar dito defeito, mas sim, para colocar-se um caso, graças ao fato de que tal sujeito conseguiu vulnerar as medidas, em princípio, perfeitamente adequadas e efetivamente estabelecidas, com a finalidade de evitar que fossem pagos corruptores com dinheiro do "Caixa 1" da entidade.

Desse modo, as pessoas jurídicas somente responderão pelos delitos que cometam determinadas pessoas individuais (as definidas no art. 31 bis 1 CP) se delas derivou uma contribuição objetiva e não permitida à sua realização, infringindo o dever que tinha de preveni-la e evitá-la. Isto é, se a infração preventiva ocorrida em seu seio gerou uma contribuição ou participação indevida e não permitida, que efetivamente se materializou no concreto delito cometido ${ }^{34}$.

Não existe responsabilidade penal da pessoa jurídica se não existe dita conexão causal. No entanto, tampouco existe, e isso não se pode esquecer, se o delito em questão pode ser evitado por qualquer meio, o que levará a que essas entidades se mantenham sempre isentas de qualquer tipo de responsabilidade penal se, por exemplo, apesar de não ter estabelecido qualquer das referidas medidas em relação aos delitos de corrupção que previsivelmente podiam ser cometidos em seu seio e em seu benefício, conseguissem, de alguma forma, impedir que algum de tais delitos fossem cometidos aproveitando-se de tal defeito preventivo (p. ex. um administrador detecta caixa 2 e a elimina e controla, evitando que o delito seja cometido ou seja realizado aproveitando-se de sua existência), algo que, como veremos, tem uma enorme transcendência no

\footnotetext{
${ }^{34}$ Adquire, assim, pleno sentido a concreta localização assinalada pelo legislador dos artigos 31 bis do nosso Código Penal, já que o que faz referido preceito é delimitar de uma forma específica de participação, no delito cometido por outro, como autor. A participação da pessoa jurídica no delito cometido e dominado pela física. Crítico, sem embargo, de dita localização se manifesta ZUGALDÍA ESPINAR, J. M., por entender que a consideração da pessoa jurídica como sujeito do Direito penal não tem nada a ver com os problemas de participação criminal, in La responsabilidad criminal de las personas jurídicas, de los entes sin personalidad y de sus directivos, Ed. Tirant lo Blanch, Valencia, 2013, pág. 62.
} 
momento de delimitar o fundamento último de sua responsabilidade.

Dessa forma, se explicaria, em qualquer caso, porque as pessoas jurídicas não respondem tão somente pela existência de um defeito preventivo em sua organização ou em seu funcionamento, nem pelos riscos abstratos ou inclusive concretos que ditos defeitos pudessem gerar, mas sim pelo delito efetivamente cometido. Responderiam por tal delito porque a infração dos deveres preventivos que estabelece o ordenamento acabaria desembocando no favorecimento da comissão do concreto fato delitivo cometido, que se deveria e poderia ter evitado, dando dita contribuição delitiva lugar ao resultado, que exige o injusto das pessoas jurídicas para poder estabelecer sua responsabilidade penal.

\section{A EXISTÊNCIA DE UMA INFRAÇÃO PREVENTIVA COLETIVA (NÃO INDIVIDUAL) COMO FUNDAMENTO DA RESPONSABILIDADE PENAL DA PESSOA JURÍDICA}

O exposto até o presente momento deixaria ainda sem resposta outra das questões básicas levantadas quando da explicação do porquê as pessoas jurídicas podem responder por delitos que cometam algumas pessoas físicas. É que se afirma, como aqui se faz, que o que fundamenta a responsabilidade de tais entidades por ditos delitos é o fato de que ocorreram em seu seio determinadas infrações preventivas que geraram riscos não penalmente permitidos, que acabaram materializando-se na produção de uma contribuição favorecedora do fato delitivo realizado por outro, faltará ainda explicar por qual razão a pessoa jurídica responderá por tais infrações e contribuições se, ao fim e ao cabo, as condutas preventivamente defeituosas que as determinaram, sempre e necessariamente, terão sido cometidas por uma ou várias pessoas físicas diferentes dela.

Com efeito, para que ocorram quaisquer das infrações dos deveres preventivos que temos falado, determinando a contribuição delitiva em relação à qual a pessoa jurídica é responsável, deve haver a possibilidade de realizar a ação normativamente exigida. Isto é, deve existir a capacidade de realizar a ação preventiva normativamente exigida, algo que pressupõe a existência de uma capacidade, a de agir e com ela, a de infringir normas, que, como vimos no começo deste trabalho, são consideradas e continuam sendo consideradas como somente predicáveis em relação às pessoas físicas e não às jurídicas. 
Seria possível entender-se então, como fazem alguns, que, na verdade, o modelo de responsabilidade penal das pessoas jurídicas estabelecidos em nosso ordenamento jurídico, por mais que as sancione pelo fato de que sua defeituosa e indevida organização ou funcionamento preventivo havia produzido uma contribuição delitiva, que se devia e podia ter evitado, não deixaria de ser nada mais do que uma "versão refinada" do tradicional sistema de responsabilização por transferência de fato alheio, do qual somente seria diferente no fato de que, em lugar de transferir a responsabilidade derivada da conduta delitiva efetuada por um indivíduo, passaria a atribuí-la pela conduta preventiva delituosa realizada por outro ${ }^{35}$. Concretamente, pela efetuada por aquele que tivesse infringido o dever preventivo em questão e pelos efeitos delitivos que houvessem se materializado em decorrência dessa atividade.

Por isso, a pergunta é imediata e obrigatória: podem as pessoas jurídicas descumprir alguma norma preventiva que possa caracterizar sua responsabilidade penal pelo delito cometido pelos seus dirigentes ou subordinados? Em caso afirmativo, qual norma seria essa?

O sistema instaurado nos artigos 31 e seguintes do nosso Código Penal, depois da reforma realizada pela LO 1/2015, caracteriza toda uma série de atuações preventivas referidas aos riscos delitivos procedentes das pessoas jurídicas às quais faz referência, cuja falta ou defeito de execução poderá autorizar que as pessoas jurídicas respondam por determinados delitos, que certas pessoas físicas cometam em seu seio ou em seu âmbito de atividade. Assim, por exemplo e como já vimos, se estabelece que a não implantação de um programa de Compliance adequado é uma das condutas que podem determinar a responsabilidade das pessoas jurídicas, caso sua execução permitisse a aparição de um risco não permitido, no qual se materializasse o delito cometido por algum dos dirigentes ou subordinados da entidade.

Existem, portanto, muitas normas que definem como se deve agir para deixar isenta de responsabilidade penal as pessoas jurídicas. O problema não é que não existam normas de determinação ou diretivas de condutas no sistema implantado. O problema está em explicar por que razão se alguém que infringe essas normas é uma pessoa física ou várias (o administrador que não implanta um programa de cumprimento, o oficial de cumprimento que não cumpre suas funções preventivas, etc....), quem responderá pela contribuição não permitida derivada de dita infração será a pessoa jurídica, em cujo seio houvesse agido e não a própria pessoa física que realizou a conduta infratora.

${ }^{35} \mathrm{Cfr}$. com o comentado supra na nota de rodapé $\mathrm{n}^{\circ} 6$. 
A nosso modo de ver, o problema que encerra essa pergunta, reiteradamente colocada por aqueles que rechaçam a possibilidade de uma responsabilidade penal da pessoa jurídica, deriva do fato de que confunde a norma de determinação que autorizará a responsabilidade de tais sujeitos.

Se prestamos um pouco de atenção ao articulado sistema de responsabilidade penal das pessoas jurídicas vigente em nosso ordenamento jurídico, nos daremos conta de que, na verdade, tal normativa somente estabelece um único dever que deve ser cumprido para que a entidade fique isenta de responsabilidade: 0 de prevenir o cometimento de determinados delitos. Caso se cumpra esse dever, a pessoa jurídica, em nenhuma hipótese, terá responsabilidade penal, por mais que não tenha cumprido alguma ou nenhuma das concretas medidas preventivas de que fala o art. 31 bis CP. De fato, analisando com maior detalhe o estabelecido no dito preceito em relação a tais medidas, nos daremos conta de que, por exemplo, ele sequer estabelece uma obrigação ou dever real de implantar programas de cumprimento, nem sanciona a entidade por não o ter realizado. O que faz é estabelecer um dever de prevenir delitos e assinala que tal dever será considerado plena e adequadamente cumprido e, portanto, não poderá acarretar responsabilidade penal alguma para a entidade, caso se respeitem em seu seio uma série de requisitos (dentre os quais está o de implantar ditos programas), cujos descumprimentos, sem embargo, não serão suficientes para dar lugar, por si sós, a sua responsabilidade.

Isso, a nosso modo de ver, já nos indica que a infração que abre as portas da responsabilidade penal da pessoa jurídica não é, na verdade, por si só nenhuma das que derivam do descumprimento de tais normas preventivas, ainda que não vinculantes, de caracterização individual, mais sim a que ocorre ao descumprir o dever geral e coletivo de prevenir a ocorrência de determinadas contribuições delitivas, que podiam e deviam ter sido evitadas, da qual fala o art. 31 bis $5 \mathrm{CP}$.

Esse é um mandato, como acabamos de assinalar, geral, já que o que obriga é prevenir determinados delitos, diante do que não requer que dito efeito deva ser conseguido de uma forma determinada ou concreta para poder considerar que se respeitou. Mas, além disso e o que é mais importante para os efeitos aqui estudados, é um coletivo, dado que, ao respaldar sua vigência diante das possíveis infrações com uma pena que poderia ter efeitos, direta ou indiretamente, sobre todos aqueles indivíduos que integram ou podem integrar a entidade, motiva a todos para que interatuem com os demais, com a finalidade de impedir que possam acontecer, no seio da entidade, os 
riscos delitivos não permitidos, que poderiam e deveriam ter sido evitados (aplicando e obrigando a aplicar adequadamente as medidas preventivas exigidas pelo art. 31 bis CP) ou melhor para que, se ditos riscos aparecem, consigam evitar que eles se materializem na contribuição delitivas que todos, como coletivo, poderiam e deveriam ter impedido e que, precisamente por isso, poderá converter a entidade, em elemento aglutinador do coletivo, que configuram e dos meios que deram lugar ao delito, em responsável penal de sua causação.

Isso responde ao fato evidente de que, quando se deixa de controlar por parte de um dos integrantes de uma pessoa jurídica, um risco delitivo previsível e que poderia ter sido controlado, para que este chegue efetivamente a materializar-se no concreto delito realizado pelos superiores ou subordinados da pessoa jurídica em questão, não somente será necessário que dito integrante individual da entidade tenha efetuado tal atuação preventivamente defeituosa, mas também será requerida da sinérgica realização de toda uma série de atuações e interações preventivamente defeituosas, efetuadas por outros indivíduos da entidade.

Resulta evidente, nesse sentido, que, para que a não implantação, por exemplo, do programa de cumprimento por parte do administrador originário de uma pessoa jurídica ou por seus sócios iniciais, que gere um risco delitivo não permitido, possa converter em responsabilidade pelo delito efetivamente cometido muito tempo depois, por outros novos dirigentes, será necessário que o risco em questão não tivesse sido controlado ou eliminado antes de que se produzisse, nem posteriormente, por nenhum dos integrantes da sociedade, nem pelos administradores que substituíram os anteriores no posto ou por um oficial de cumprimento posteriormente designado. No entanto, além disso e não se deve esquecer-se jamais, que também será necessário que os titulares ou sócios da entidade, apesar de existir dito perigo corporativo, realizem ou mantenham sua contribuição à pessoa jurídica em que ocorria, já que, se não realizaram a contribuição ou a retiraram, a pessoa jurídica, evidentemente, haveria deixado de existir ou, pelo menos, não poderia ter atuado, diante do que dificilmente poderia ter contribuído para a realização do delito.

Desse modo, o que determina a ocorrência da contribuição delitiva que fundamenta a responsabilidade penal da pessoa jurídica não é a realização de um simples comportamento preventivo defeituoso individual, mas sim a confluência, junto a tal conduta, de toda uma série de interações realizadas, de forma difusa e em muitos casos assíncronas, por muitos outros integrantes, infringindo o dever coletivo que o 
ordenamento Ihes dirigia, para que interagissem com o fim de evitar a ocorrência do resultado. Assim sendo, não parece lógico então que se possa responsabilizar pela produção da comentada contribuição delitiva individual, que lhe correspondesse, mas sim a todos aqueles que, de forma difusa, sinérgica e coletiva, permitiram que o defeito preventivo existente na entidade se materializasse em tal resultado. Isto é, a aquele difuso e cambiante, cuja interação acumulada e que se manteve no tempo no seio da entidade deu lugar à contribuição delitiva, que haveria produzido e que se podia e devia ter evitado. Um coletivo, como dissemos, difuso e cambiante e que, precisamente por isso, somente pode ser identificado e delimitado mediante a referência à pessoa jurídica que agrupa ou agrupou seus integrantes e sustentou o risco que sua defeituosa interação gerou. Isto é, a pessoa jurídica que representa e agrupa a todo o difuso coletivo responsável pela contribuição delitiva finalmente produzida e que, precisamente por isso, é e pode ser responsabilizada por sua causação.

\section{PRINCÍPIO DA CULPABILIDADE E RESPONSABILIDADE PENAL DA PESSOA JURÍDICA: DOLO OU IMPRUDÊNCIA DAS PESSOAS JURÍDICAS?}

Do exposto até o momento se deduz que o sistema de responsabilidade penal da pessoa jurídica se fundamenta na realização de uma infração normativa, imputável à ela mesma e não a um indivíduo concreto ou vários determinados e definíveis dentre os que a integram ou tenham integrado. Ademais e por outro lado, é um sistema que permite responsabilizá-la pelo delito cometido por um terceiro (um indivíduo), já que a converte em responsável por ter dado lugar a uma contribuição coletivamente evitável à realização do referido delito.

Esses elementos constituem, portanto, os referentes básicos do tipo objetivo do injusto, do qual se poderá responsabilizá-la.

Sem embargo, para que possa existir responsabilidade penal e que se possa aplicar verdadeiras penas a qualquer sujeito e, portanto, também às pessoas jurídicas, é necessário, por imperativo do princípio da culpabilidade e tal e qual exige 0 art. 5 do nosso Código penal, que quem realize a infração penal em questão possa ser responsabilizado por ter a ter feito, seja a título de dolo, seja, pelo menos, a título de culpa.

O primeiro que se deve frisar a esse respeito é que, do mesmo modo que não se pode transferir a infração preventiva ou a concreta conduta delitiva objetiva que tenha 
realizado uma pessoa física à jurídica, para condená-la pela sua realização, sem infringir o princípio da culpabilidade, tampouco é possível utilizar-se de dito expediente para assinalar-lhe o dolo ou a culpa que fundamente sua responsabilidade.

É impossível, portanto, fundamentar a responsabilidade subjetiva da pessoa jurídica pela contribuição ao delito cometido produzida em decorrência da infração de um dever preventivo que se lhe dirige, observando os conhecimentos ou a consciência sobre a realização de tal infração ou do possível acontecimento do resultado que tiveram ou deveriam ter algum ou todos os integrantes de sua organização ${ }^{36}$.

Sem embargo e por outro lado, tampouco é possível sustentar que se possa, sem mais, como feito por algum autor, que, considerando que a pessoa jurídica por si mesma e dada sua natureza de pura ficção jurídica, não pode conhecer, nem querer, sua responsabilidade, sempre e necessariamente, deverá estar sustentada em sua imprudência inconsciente, por ser dito título de atribuição uma categoria puramente normativa e não psicológica que, precisamente por isso, resulta mais adequada para poder responsabilizá-la subjetivamente ${ }^{37}$.

Para verificar se o sistema de responsabilidade penal das pessoas jurídicas, vigente na Espanha, pune as contribuições delitivas que essas gerem, como coletivo, de forma dolosa ou culposa (inconsciente ou não) deve-se verificar aos preceitos normativos que fundamentam e delimitam dita responsabilidade, sem que seja possível utilizar, simples e diretamente, aquele dentre os possíveis títulos de imputação subjetiva existentes, que resulte mais fácil de demonstrar para poder sancioná-las, excluindo sem mais todos aqueles outros que, de acordo com sua concepção tradicional, não pareçam adequados ou idôneos para poder fazê-lo.

Em outras palavras, a pergunta que temos que fazer não é como se poderia responsabilizar subjetivamente as pessoas jurídicas de forma mais fácil, pelos delitos cuja realização houvessem contribuído coletiva e objetivamente, mas sim, como exige o sistema vigente, que ocorra essa contribuição causal não permitida, para que se possa

\footnotetext{
${ }^{36}$ Tem outra opinião, sem embargo, GÓMEZ-JARA DÍEZ, C. in "El injusto típico de la persona jurídica (tipicidad)" cit. ant., pág. 138 e ss.

${ }^{37}$ RODRÍGUEZ RAMOS, L. quem, ademais, frequentemente, afirma que: "esa negligencia corporativa siempre se podrá achacar en último término a los administradores, directivos y mandos intermedios que deberían haber evitado ese descuido previsible y evitable en cada caso concreto, aún cuando dicha persona no merezca sanción penal por cualquier motivo, incluida la previsión del art. 12 CP", in "Sobre la culpabilidad de las personas jurídicas. (Al hilo de las STS 514/2015, 154 y 221/2016)", in Diario La Ley, no 8766, 2016, http://diariolaley.laley. es (últ. vis. 5-9-2018); uma postura semelhante que, de fato, vem defender que a infração do dever de cuidado, de acordo com referido autor, sustenta a responsabilidade da entidade, especialmente quando realizada por algum de ditos indivíduos, diante do que se rompe com a exigência de responsabilidade penal pessoal e por fato próprio, que referido autor dizia pretender sustentar.
} 
considerar se a entidade da qual procedeu era subjetivamente responsável ou culpável de sua produção.

A nosso juízo, a resposta a essa questão vem dada pelo próprio teor literal do art. 31 bis CP.

É em dito preceito onde, em primeiro lugar e como visto, se estabelece que a entidade, como coletivo, tem a obrigação ou dever de prevenir determinados delitos. Mas é também no mesmo onde se passam a fixar toda uma série de requisitos mais concretos e específicos (realização de um mapa de riscos, criação de um modelo preventivo adequado, etc....), cuja concorrência, garantia e asseguramento por parte do coletivo integrante da pessoa jurídica, manterá os riscos delitivos procedentes da entidade, dentre os quais aqueles que geralmente se permite gerar, enquanto que sua infração os converteria em riscos não permitidos, abrindo assim as portas para que se the pudesse atribuir responsabilidade pelos delitos nos quais os mesmos chegassem a se materializar.

São estabelecidos assim alguns parâmetros fundamentais na hora de delimitar a possível responsabilidade penal das pessoas jurídicas. Caso se respeite as pessoas jurídicas elas não poderão ser responsabilizadas, em nenhum caso, pelos delitos que cometam, em seu seio e em seu benefício, os sujeitos de que fala o art. 31 bis $1 \mathrm{CP}$. Caso não se respeite a pessoa jurídica, tal fato pode, ainda que sem motivo, possibilitar que se the atribua responsabilidade penal.

Parece então que o que nosso legislador faz, ao estabelecer ditos parâmetros preventivos, é concretizar o modo com que as pessoas jurídicas, como coletivo, teriam que cumprir o dever de prevenir delitos que lhes dirige nosso ordenamento, para fazê-lo de forma plenamente diligente e manter, em consequência, sua atividade completamente dentro do geralmente permitido, resultando, portanto, o descumprimento de ditos referentes fundamental para abrir as portas da possível responsabilidade penal da entidade.

De fato, nada mais, aparte de dito descumprimento, exige nosso Código para avaliar aquela infração que permitiria atribuir responsabilidade penal a tais entidades por delitos dos quais temos falado. Será suficiente que ocorra algum de ditos descumprimentos preventivos e este dê lugar à aparição de um risco não permitido que chegue a materializar em uma contribuição delitiva, de que falamos anteriormente, para que se possa sancionar a pessoa jurídica.

Isso lembra significativamente ao juízo que a forma tradicional tem 
fundamentado a realização culposa de delitos por parte das pessoas físicas. A infração do dever objetivo de cuidado que deve cumprir uma norma penal: juízo que, sem embargo, neste caso, estará referido à infração da norma de cuidado com que se deve cumprir o dever coletivo de prevenir determinados delitos e que, precisamente por isso, não analisa exclusivamente a forma em que alguém ou, inclusive, vários dos integrantes da entidade terão infringido o dever preventivo de cuidado que thes corresponde, mas sim a maneira em que a interação do coletivo teria levado à produção de um contribuição delitiva, que deveriam e podiam ter evitado, interagindo de forma mais diligente.

Precisamente por isso e todos os efeitos que nos ocupam aqui, é indiferente que algum dos integrantes da pessoa jurídica houvesse podido infringir o dever preventivo individual que the correspondesse de forma dolosa ou, inclusive, que houvesse feito já com intenção de favorecer o cometimento do delito efetivamente realizado, como ocorreria, por exemplo, se o administrador deixasse dolosamente de criar ou implantar medidas preventivas adequadas, que deveria ter realizado no modelo preventivo da pessoa jurídica, que administrava para prevenir fraudes, precisamente, porque tinha a intenção de cometer alguma, usando seu cargo e em benefício da entidade.

E que ditos indivíduos infrinjam seus deveres preventivos específicos de uma forma ou de outra, dolosa ou culposamente, resulta, em princípio, por si só, indiferente para a responsabilidade da pessoa jurídica, uma vez que, como já visto, esta não responde pela forma com que dito sujeito tivesse violado seu dever individual, mas sim, precisamente, pela maneira com que o coletivo infringiu o dever preventivo geral que $o$ ordenamento dirigia a todos que o integravam, para que efetuassem de forma adequada o objetivo de evitar que dita infração preventiva individual ocorresse ou chegasse a materializar-se no cometimento de um delito. Um dever coletivo tal, que o sistema do art. 31 bis e seguintes do nosso Código penal entenderá como descumprido tão logo se verifique que os integrantes da entidade interagiram de forma coletiva de um modo desconforme ao que deviam e podiam ter feito, dando lugar assim a que o risco não permitido se gerasse, se mantivesse e, finalmente, chegasse a realizar-se no referido resultado delitivo, que podiam e deviam ter evitado, entre todos.

Assim, pois, o sistema de responsabilidade penal das pessoas jurídicas que se vem analisando pune, a partir do exato momento em que a contribuição delitiva que acarretou houvesse se materializado em virtude de uma incorreta e não buscada interação de seus integrantes. Isto é, como resultado de uma mera falta de cuidado preventivo coletivamente exigido em seu funcionamento, algo que, evidentemente, se 
aproxima ao fundamento subjetivo desta responsabilidade coletiva àquilo que tradicionalmente se definiu à culpa individual.

Contudo, não se deve deixar passar batido o fato de que, do mesmo modo que nosso Código penal prevê, em seus artigos 31 bis CP e seguintes, um sistema que permite punir as pessoas jurídicas simplesmente por não ter prevenido e evitado correta e diligentemente determinadas contribuições delitivas previsíveis e que podiam e deviam ter controlado, convertendo assim seu controle negligente no fundamento último de sua reprovabilidade subjetiva, também contempla sanções para aquelas outras entidade que, não somente determinaram que se produzissem contribuições não permitidas e negligentes à realização de delitos, mas que diretamente criaram e funcionaram para favorecer e fomentar a execução de dita modalidade de delitos.

Estamos falando das denominadas "empresa de fachada". É dizer, daquelas pessoas jurídicas que, não é que atuem geralmente de forma legal no mercado, por mais que, ao não ter se organizado de forma correta, desde o ponto de vista preventivo, tenham podido favorecer de forma negligente a realização de um delito, seja eventualmente ou inclusive de forma reiterada, mas sim daquelas entidades que foram criadas e teriam como única e exclusiva finalidade e função a de contribuir com a realização de condutas delitivas, sendo, por isso, sua atividade legal absolutamente inexistente ou puramente residual ${ }^{38}$.

Essas últimas pessoas jurídicas, a juízo das Circulares 1/2011 ${ }^{39}$ e 1/2016 40 da Procuradoria-Geral de Justiça e também de alguma controvertida Sentença do Tribunal Supremo, como a 154/2016, de 29 de fevereiro ${ }^{41}$, teriam sido criadas com fraude à lei e, por isso, poderiam ser dissolvidas automaticamente.

Assim, ambas instituições se inclinavam por rechaçar, não somente que as pessoas jurídicas de "fachada" pudessem ser punidas, conforme o estabelecido nos art. 31 bis e seguintes do nosso Código penal, como diretamente pudessem ser punidas de qualquer forma pelo Direito penal, ao entender que era possível e, de fato, se teria que dissolvê-las civilmente, por terem sido criadas com fraude à lei (art. $6.4 \mathrm{CC}$ ), algo que, por outro lado e a juízo de alguns autores que compartilhavam essa postura, faria com que, na verdade, nunca tivesse gozado de verdadeira personalidade jurídica e, portanto, permitira, que se lhes pudesse aplicar as consequências acessórias do art. $129 \mathrm{CP}$, já

\footnotetext{
${ }^{38}$ Sobre essa diferenciação e seus efeitos, veja-se o comentado por GALÁN MUÑOZ, A. Fundamentos y límites de la responsabilidad penal de las personas jurídicas..., cit. ant., pág. 89 e ss. e 245 e ss.

39 (Tol 2119121)

40 (Tol 5616306)

41 (Tol 5651211).
} 
durante a própria fase de investigação ${ }^{42}$.

Sem embargo, tais posturas enfrentam, a nosso modo de ver, dois problemas realmente sem salvação.

O primeiro deriva do fato de que pretendem deixar completamente à margem do sistema de responsabilidade penal do nosso Código e, consequentemente, também de suas garantias, entidades, cuja concreta natureza de "sociedades de fachada" ou não, dificilmente pode ser constatada à margem de um procedimento penal e antes que este termine com uma sentença que declare dito caráter, dado que isso poderia dar lugar a situações manifestamente injustas e dificilmente reparáveis, como a de que poderia ocorrer caso se dissolvesse uma entidade, demonstrando-se depois que não tinham tal natureza ${ }^{43}$.

Por isso que, ademais e por outro lado, as citadas propostas também enfrentam uma grave dificuldade de natureza substantiva e legal, já que caso se chegue a entender, como sustentam, que as "sociedades de fachada" não são, na realidade, verdadeiras pessoas jurídicas, diante do que devem ser simplesmente dissolvidas e consideradas nulas desde o nascimento, sem que possam estar sujeitas a penas em sentido estrito, não se conseguiria compreender a razão, por exemplo, que o art. $520 \mathrm{CP}$ estabelece que os tribunais, nos casos de delito de associação ilícita do art. $515 \mathrm{CP}$, “... determinarão a dissolução da associação ilícita” ou o art. 570 quater CP afirme que os juízes deverão determinar, em relação às organizações e grupos criminosos e terroristas, “... a dissolução da organização ou grupo e, se for o caso, quaisquer outras consequências dos artigos 33.7 e 129 deste Código".

A pergunta diante de ditas disposições é evidente e imediata. Se as "sociedades de fachada" não têm personalidade jurídica e devem ser consideradas nulas e

\footnotetext{
${ }^{42}$ Assim assinala ZUGALDÍA ESPINAR, J. M. La responsabilidad criminal de las personas jurídicas, de los entes sin personalidad y de sus directivos ..." cit. ant., pág. 109.

${ }^{43}$ Nesse sentido, assinala MARTíN SAGRADO, O. que declarar nula ou inexistente uma entidade durante a fase de investigação e aplicar-lhe, uma vez privada de personalidade jurídica, as medidas do art. 129 $\mathrm{CP}$, como pretendem alguns, poderia gerar prejuízos irreparáveis à entidade afetada, se, finalmente e depois da instrução processual, se constatasse que não havia cometido delito algum que permitisse punila ou que a suposta sociedade de fachada não era realmente tal, in "El decomiso de las sociedades pantalla", Diario La Ley, № 8769, 2016, en http://diariolaley.laley.es (últ. vis. 1-9-2018). Precisamente por isso, consideramos, como reconheceu expressamente, por exemplo, a decisão de 19 de maio, da Audiência Nacional, que, para declarar uma pessoa jurídica como sociedade de fachada, faz-se necessária uma decisão judicial específica e motivada, que deve ser precedida de um procedimento que permita à entidade defender-se de dita qualificação, evitando assim as consequências prejudiciais que tal consideração pode acarretar; ambas exigências que impedirão que se possa negar, tal e como pretendem os defensores das posturas anteriormente comentadas, o caráter de imputado a qualquer pessoa jurídica pelo mero fato de que se suspeite que, na verdade, era uma mera "empresa de fachada" e, portanto, que se lhe possa privar, ab initio e sem mais, do seu caráter de sujeito e não de mero objeto do Direito penal.
} 
inexistentes ex tunc, qual sentido têm, então, que esses preceitos obriguem ao juiz a dissolver as pessoas jurídicas que amparem associações ilícitas ou criminais, se estas, por definição, serão sociedades de fachada? Não é óbvio que, ao ter sido criadas com fraude à lei, seriam completamente nulas e nunca teriam existido? Por outro lado, como serão aplicadas, por exemplo, as penas do art. 33.7 CP às sociedades criminais, das que fala o art. 570 quarter $\mathrm{CP}$, si ditas penas somente são aplicáveis a entidades dotadas de personalidade jurídica e estas carecem dela, desde o início?

A nosso juízo, a resposta a essas perguntas é evidente. Esses preceitos aludem à dissolução como a única consequência necessária e obrigatoriamente derivada da constatação de que a entidade em questão era uma associação ilícita ou uma organização criminosa ou terrorista e, portanto, uma verdadeira "empresa de fachada", porque, precisamente, a constatação de dita qualidade é aquilo que fundamentará que seu injusto organizativo resulte de tal gravidade que já não somente se possa, mas que se deva necessariamente sancioná-la com a pena de dissolução, por mais que também seja possível aplicar outras penas do art. 33.7 CP.

Com efeito, a dissolução das associações ilícitas e organizações ou grupos criminosos ou terroristas dotados de personalidade jurídica não é uma simples dissolução civil. Se assim fosse, não seria necessário demonstrar o cometimento do delito de associação ilícita ou de organização ou bando criminal ou terrorista para poder dissolvê-las. Bastaria constatar que a entidade teria sido criada com fraude à lei.

A dissolução a que se referem ditos preceitos é uma dissolução penal, que somente poderá ser aplicada depois da efetiva constatação judicial de que a pessoa jurídica a que seja imposta estava diretamente constituída e orientada a favorecer o cometimento dos delitos por parte de pessoas físicas e não havia simplesmente favorecido, de forma pontual ou inclusive repetida, mas não sistemática e exclusiva, a realização de ditos fatos, por não ter se organizado adequadamente. Esse fato, o de estar diretamente dirigida a favorecer o cometimento de delitos, constitui precisamente a nosso modo de ver o injusto organizativo que legitima a imposição obrigatória de tão severa pena (a de dissolução) às referidas entidades, sem a necessidade de ter que provar que sua atividade favoreceu o cometimento de nenhum outro delito, em concreto. Mas, também e por outro lado, é o que exclui que se lhes possa aplicar o sistema de responsabilidade previsto no art. 31 bis e seguintes do nosso Código penal para imporIhe tal sanção, dado que não tem sentido que se puna a um sujeito coletivo pelo mero fato de que não previna adequadamente alguns delitos, quando precisamente havia sido 
criado para favorecer a sua realização ${ }^{44}$.

Acertam, portanto, as já citadas Circulares da Procuradoria-Geral de Justiça e a Sentença 154/2016 do Tribunal Supremo quando afirmam que as sociedades de fachada não podem ser processadas conforme os parâmetros dos artigos 31 bis e seguintes do nosso Código, previsto para organizações que simplesmente não se organizam de forma adequada e diligente para prevenir delitos.

Sem embargo, e a nosso modo de ver, o anterior não pode levar, como também defendem, que as pessoas jurídicas que sejam tidas como tais, fiquem à margem do sistema penal e carentes de qualquer garantia.

Na verdade, a responsabilidade penal das sociedades de fachada e sua concreta pena será determinada de acordo com o disposto nas normas reguladoras das associações ilícitas e as organizações e grupos criminosos ou terroristas; regras essas que estabelecem que ditas entidades, em caso de ser consideradas como tais, tenham sempre e necessariamente que ser sancionadas com a pena de dissolução, isso sim, depois de um juízo com as devidas garantias para comprovação de dita natureza.

Assim se estabelece um segundo e alternativo sistema sancionador para as pessoas jurídicas. Um que está especificamente criado para as organizações criminosas ou pessoas jurídicas "de fachada" e que é mais duro e completamente diferente do previsto nos artigos 31 bis e seguintes do nosso Código penal para o resto das pessoas jurídicas, incluídas as meramente instrumentais.

Este último sistema, o dos artigos 31 bis e seguintes do nosso Código Penal, punirá as pessoas jurídicas que não previnam adequada ou diligentemente os delitos que deviam prevenir, apesar de poderem e deverem fazê-lo e, como consequência disso, terminam contribuindo de forma indevida, não permitida e culposa para que sejam cometidos ditos delitos, sendo que a gravidade deste é fundamental na hora de determinar a pena que deverá ser aplicada à entidade que os favoreceu.

O primeiro, o dos art. 520 e 570 quater CP, por sua parte, se aplicará tão somente àquelas entidade que sejam criadas e organizadas precisamente com o fim de favorecer e facilitar o cometimento de delitos (as sociedades de fachada), o que, sem dúvidas, determinará o aparecimento, em seu seio, de interações coletivas que refletirão a existência em tais pessoas jurídicas de uma verdadeira "cultura corporativa criminógena",

\footnotetext{
${ }^{44}$ Desse modo, se entende, por exemplo que o art. 576, 5, CP, preveja a possível responsabilidade penal das pessoas jurídicas por delitos de financiamento do terrorismo da qual fizeram parte, observando exclusivamente o estabelecido no art. 31 bis CP e não sendo uma organização exclusivamente dedicada a realizar tais fatos, o que a transformaria em uma organização suscetível de ser dissolvida diretamente, em atendimento ao fixado no art. 570 quater $\mathrm{CP}$.
} 
diretamente tendente a favorecer e fomentar o cometimento de delitos por parte de seus integrantes e colaboradores, dando-se assim lugar a um injusto corporativo diferente e muito mais grave que o que sanciona o sistema anteriormente mencionado (o do art. 31 bis CP). Um injusto que, precisamente por isso, deve ser sempre e obrigatoriamente castigado com a imposição da pena de dissolução, sem necessidade de esperar que dita perigosa cultura corporativa cheque sequer a se concretizar e materializar na efetiva realização de algum delito individual e, evidentemente, sem ter que cumprir com todos os requisitos que estabelece $o$ art. 66 bis $2^{\mathrm{a}}$ in fine $\mathrm{CP}$, que exige, para poder aplicar tal pena a qualquer pessoa jurídica, que fosse uma verdadeira sociedade de fachada.

É possível diferenciar, portanto, dentro do nosso ordenamento jurídico, um sistema que contempla uma responsabilidade penal corporativa pela contribuição de delitiva que poderiam efetuar o coletivo que integra as pessoas jurídicas de forma que poderia ser considerada como errada ou imprudente e outro que castigaria a que realizasse ou, simplesmente, tenderia a realizar uma forma que, guardadas as distâncias, poderia ser considerada como valorativamente equivalente, quanto ao seu nível de gravidade, à que tradicionalmente tem fundamentado a responsabilidade individual dolosa, ainda que, evidentemente, nenhuma das duas categorias (nem a culpa da primeira, nem o dolo da segunda) responderia exatamente à configuração tradicional que ambas categorias do delito têm, quando se predicam em relação às pessoas físicas.

Tanto em um como no outro sistema existem interações coletivas efetuadas por aqueles que conformam ou conformarão as entidades às quais se vai sancionar, que permitem que nosso ordenamento se Ihes atribua a estas, e não a um ou a vários de seus concretos integrantes, os efeitos ou resultados delitivos, que configuram o injusto coletivo que abrirá as portas para a sua correspondente responsabilidade e sanção penal. Se Ihes irá aplicar, portanto, em quaisquer dos casos, uma verdadeira pena sustentada pela sua própria infração e em sua culpabilidade, ao mesmo tempo em que uma responderá de forma adequada e proporcional as mui distintas formas de aparição e periculosidade, que poderiam ter as interações efetuadas em seu seio, que poderiam desembocar em contribuições delitivas coletivamente reprováveis para o ente coletivo que as havia gerado. Evidentemente, isso não leva a que o sistema de responsabilidade penal da pessoa jurídica esteja completamente fechado e seja perfeito.

Se o previsto para as pessoas físicas não o é, mesmo depois de séculos de laborioso e sisudo desenvolvimento, dificilmente aconteceria algo distinto para um sistema tão recente de criação como o "jovem" sistema implantado para as referidas 
entidades coletivas. Ainda resta muito a fazer.

Sem embargo, a nosso modo de ver, o que parece que se possa discutir é que a regulação vigente em nosso país, atualmente, nos apresenta um interessante caminho a seguir na hora de responsabilizar-se penalmente as pessoas jurídicas, dado que delimita não somente quais condutas e quais contribuições delitivas podem gerar sua responsabilização e por que se deveria culpabilizar as entidades e não seus integrantes pelo cometimento de delitos, além do que deixa claro que nem todas as contribuições delitivas que sejam realizadas ou possam ocorrer no âmbito de uma pessoa jurídica podem ser tratadas ou sancionadas de igual forma pelo Direito penal, algo que, sem dúvidas, anima a seguir fazendo o caminho que apenas acabamos de começar.

Recebido em 17/11/2020

Aprovado em 02/12/2020

Received in $17 / 11 / 2020$

Approved in 02/12/2020 